\title{
REGULAR ARTICLE \\ INFLUENCE OF CADMIUM ON GROWTH AND BIOCHEMICAL CONTENTS OF TOMATO PLANTS
}

\author{
A. NATARAJAN 1 , P. VIJAYARENGAN ${ }^{*}$, M. VIJAYARAGAVAN ${ }^{2}$
}

${ }^{1}$ Department of Botany, Annamalai University, Annamalai Nagar 608002, Tamilnadu India

${ }^{2}$ Department of Botany, Government Arts College, Thiruvannamalai, Tamilnadu, India

\begin{abstract}
The increasing concentrations $(10,25,50,75$ and $100 \mathrm{mg} / \mathrm{kg}$ ) of soil cadmium on growth and biochemical contents in tomato plants were analysed on 3oth sampling days. Control plants were maintained separately. Plants were grown in pots containing $3 \mathrm{~kg}$ of air dried sandy loam soil and treated with different concentrations $(\mathrm{mg} / \mathrm{kg})$ of cadmium $(0,10,25,50,75 \mathrm{and} \mathrm{100)}$. Treatments decreased the growth parameters such as root and shoot length and biochemical constituents such as protein, (except, proline and phenol content) contents in tomato plants compared to untreated plants. The shoot length of cadmium treated tomato plants was higher than the root length. proline and phenol content of root of tomato plants was higher than the shoot.
\end{abstract}

Keywords: Cadmium, Tomato, Growth, Biochemical, Phenol.

\section{INTRODUCTION}

Throughout the world the heavy metal pollution is causing great threat all organisms [1]. Accumulation of heavy metals in plants may be a serious problem [2], since there are chances of entering to the potential food web [3]. The contamination of food chain by plant accumulated heavy metals is current hot issue worldwide, as it causes serious health hazards, and identification and control should be taken care with serious actions [4-5].

The present study aimed to identify the extent of changes in growth parameters such as, root and shoot length and biochemical constituents such as, protein, proline and phenol contents in tomato plants due to cadmium toxicity.

\section{MATERIALS AND METHODS}

The certified seeds of tomato were obtained from Tamilnadu Agriculture University (TNAU), Agricultural Research Station, Aduthurai, Thanjavur district (TN), India. Seeds with uniform size, colour and weight were chosen for the experimental purpose. The soil used in the experiment was red soil $40 \%+$ sandy loam $60 \%$ in nature and $\mathrm{pH}$ of the soils was 7.2. It contains major nutrients of $118 \mathrm{~kg}$ available $\mathrm{N}, 88 \mathrm{~kg} \mathrm{P}$ and $106 \mathrm{~kg} \mathrm{k} / \mathrm{ha}$ and micronutrients of $21.89 \mathrm{mg}$ available $\mathrm{Cu}, 219.11 \mathrm{mg} \mathrm{Fe}, 168$ $\mathrm{mg} \mathrm{Mn}$ and $28.13 \mathrm{mg} \mathrm{Zn} / \mathrm{kg}$, cadmium was not available in this experimental soil. The cadmium chloride $\left(\mathrm{Cd} \mathrm{Cl}_{2} \quad 1 / 2\right.$
$\mathrm{H}_{2} \mathrm{O}$ ) was used as cadmium source.

The pot culture experiments were conducted in Botanical Garden, Annamalai University. Tomato plants were grown in pots containing untreated soil (Control) and soil mixed with various levels of cadmium (viz., 10, 25, 50, 75 and 100 $\mathrm{mg} \mathrm{kg}$ ). The inner surfaces of pots were lined with a polythene sheet. Each pot contained $3 \mathrm{~kg}$ of air dried soil. Six seeds were sown in each pot. All pots were watered to field capacity daily. Plants were thinned to a maximum of three per pots, after a week of germination. Each treatment including the control was replicated three times.

The plant samples were collected on 3oth days after sowing. Three plants from each replicates of pot were analyzed for the various growth parameters such as root and shoot length and biochemicals such as, protein, proline and phenol contents. Roots and shoots of treated and control plants were used for the estimation of protein contents as per Lowry et al. [6], proline as per Bates et al. [7] and total phenols as per Singleton and Rossi [8] methods.

\section{RESULTS AND DISCUSSION}

Physio-chemical properties of the soil are given in table-1.

The effect of cadmium on growth parameters such as root and shoot length of tomato plants are presented in Figure-1. All growth parameters of cadmium treated plants $(10,25$,

Received 01 March 2018; Accepted o3 April 2018

${ }^{*}$ Corresponding Author

P. Vijayarengan

Department of Botany, Annamalai University, Annamalai Nagar 608002, Tamil Nadu, India

Email: natarajansiva78@gmail.com; drpvrengan@yahoo.com

( This article is open access and licensed under the terms of the Creative Commons Attribution License (http://creativecommons.org/licenses/by/4.o/) which permits unrestricted, use, distribution and reproduction in any medium, or format for any purpose, even commercially provided the work is properly cited. Attribution - You must give appropriate credit, provide a link to the license, and indicate if changes were made. 
50, 75 and $100 \mathrm{mg} \mathrm{kg}^{-1}$ ) gradually decreased when compared to untreated plants. The maximum root and shoot length were recorded in control plants on 3oth sampling days. The minimum value of all growth parameters were found in 100 $\mathrm{mg} \mathrm{\textrm {kg } ^ { - 1 }}$ of cadmium treated plants. Our results are in agreement with the findings of Juwarkar and Shende and Yi and Ching [9-10]. Xu et al. [11] also suggested that the higher concentrations of cadmium can cause cell growth inhibition. Schutzendubel et al. [12] who reported that the cadmium also induced the generation of reactive oxygen species (ROS). The growth reduction also reported by Hagemeyer and Breckle [13] and Marcano et al. [14].

\section{Protein content}

Perusal of data in Figure-2, reveal that the plants raised in cadmium treated soils were poorer in protein contents as compared to control plants in 3oth sampling days. Higher the cadmium contents lesser the values of protein in both root and shoots of tomato. The above results were in agreement with the findings of Costa and Spitz [15] in Lupinus albus, Costa and Morel [16] in lettuce, Satyakala [17] in Pistia stratiotes and Dinakar et al. [18] in Arachis hypogaea. The decrease in protein content can be compared with the work of Dietz et al. [19]. Cadmium induced reduction of protein content was also reported by Jana [20]. The inhibitory action of cadmium on amino acid and protein content may be due to binding of metals with sulphydryl group of protein, causing deleterious effect in the normal protein form [21].

\section{Proline content}

The results showed in Figure-3 indicated that the minimum proline content was in control (0.686, 0.488). With increase of cadmium $(10,25,50,75$ and $100 \mathrm{mg} \mathrm{kg}$ ${ }^{1}$ in soil), proline content was strongly increased in 30 th sampling days. Maximum content of root and shoot was observed at $100 \mathrm{mg} \mathrm{kg}^{-1}$ cadmium level $(1.754,0.984)$ of soil. This can be compared with earlier reports [18, 22-26].

\section{Phenol content}

Result indicated that increasing levels of cadmium treatment markedly increased the phenolic content of tomato roots and shoots (Figure-4). An enhancement of the amount of phenolic compounds can be observed under different environmental factors and stress conditions [27]. Our results are in agreement with earlier reports [28, 29].

Table 1: Physio-chemical properties of the experimental soil

\begin{tabular}{|c|c|c|c|c|c|c|c|c|c|c|c|c|}
\hline \multirow[t]{2}{*}{ Soil type } & \multirow[t]{2}{*}{ pH } & \multirow[t]{2}{*}{ EC } & \multirow{2}{*}{$\begin{array}{l}\text { Moisture } \\
\text { content }\end{array}$} & \multirow{2}{*}{$\begin{array}{l}\text { Organic } \\
\text { carbon }\end{array}$} & \multicolumn{3}{|c|}{ Available(kg/h-1) } & \multicolumn{5}{|c|}{ DTPA-TEA extractable $\left(\mathrm{mg} \mathrm{kg}^{-1}\right)$} \\
\hline & & & & & $\mathbf{N}$ & $\mathbf{P}$ & $\mathbf{K}$ & $\mathbf{C u}$ & $\mathbf{F e}$ & Mn & $\mathbf{Z n}$ & $\mathbf{C d}$ \\
\hline Red+Sandy loam & 7.2 & 0.4 & 20.10 & 0.56 & 118 & 88 & 106 & 21.89 & 219.11 & 168 & 28.13 & - \\
\hline
\end{tabular}

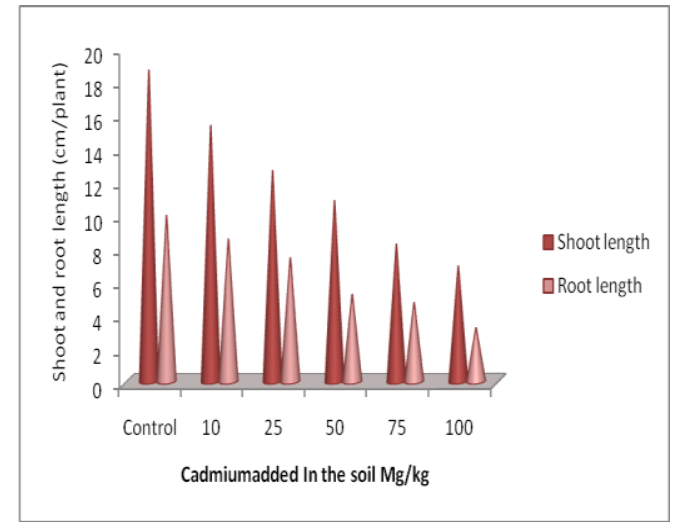

Fig. 1: Effect of cadmium on root and shoot length of tomato plants

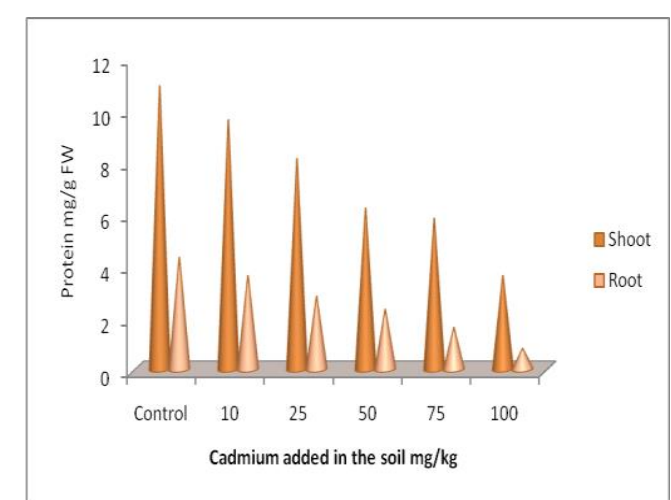

Fig. 2: Effect of cadmium on protein content of tomato plants

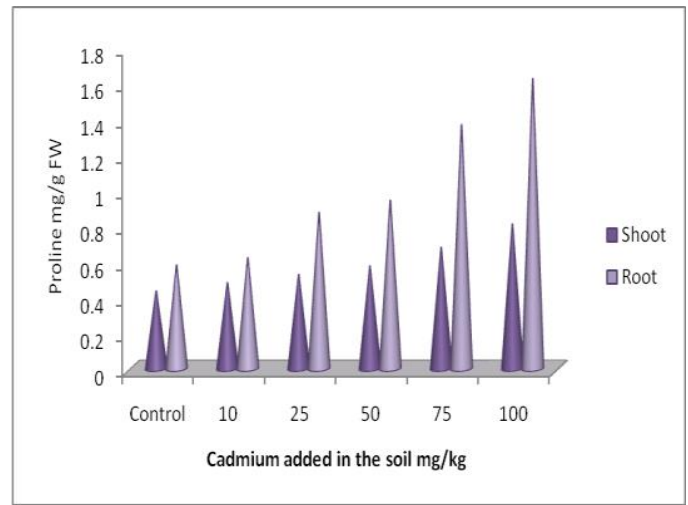

Fig. 3: Effect of cadmium on proline content of tomato plants

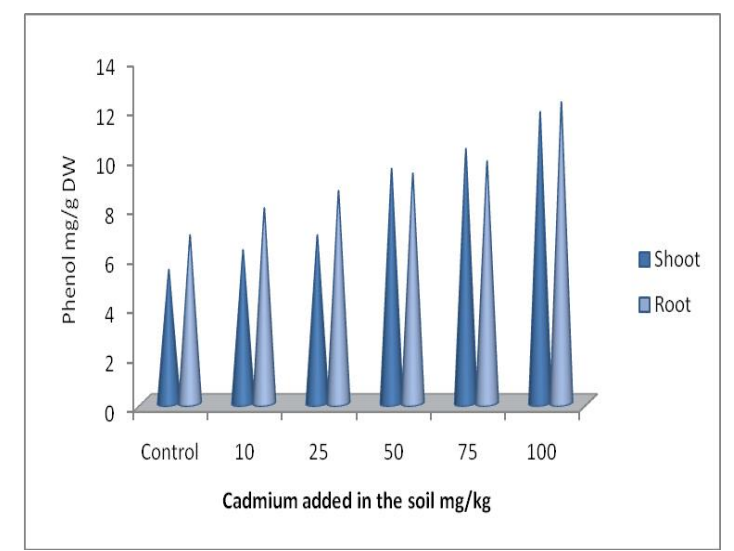

Fig. 4: Effect of cadmium on phenol content of tomato plants 


\section{REFERENCES}

1. Das P, Samantaray S, Rout GR, Studies on Cadmium toxicity in plants. A review. Environ Poll 1997;18:2936.

2. Sanita di Toppi L, Gabbrielli R, Response to cadmium in higher plants-A review. Env Exp Bot 1999;41:105130.

3. Fargasova $\mathrm{A}$, Effect of $\mathrm{Pb}, \mathrm{Cd}, \mathrm{Hg}$, As and $\mathrm{Cr}$ on germination and root growth of Sinapis alba seeds. Bull Environ Contam Toxicol 1994;52:452-456.

4. Sharma RK, Agrawal M, Marshall FM, Heavy metals in vegetables collected from production and market sites of a tropical urban area of India Food Chemical Toxicology 2009;47:583-591.

5. Lokeshwari H Chandrappa GT, Imapct of Heavy Metal Contamination of Bellandur Lake on Soil and Cultivated Vegetation, Current Science 2006;91:622627.

6. Lowry $\mathrm{OH}$, Rosebrough NJ, Farr AL, Randall RJ, Protein measurement with Folin phenol reagent. J Biol Chem 1951;193, 265-275.

7. Bates LS, Waldren RP, Teare IW, Rapid determination of free proline for water stress studies. Plant Soil 1973;39:205-205.

8. Singleton VL, Rossi JA, Colorimetry of Total Phenolics with Phosphomolybdic-Phosphotungstic Acid Reagents. Am J Enol Vitic 1965;16:144-158.

9. Juwarkar AS, Shende GB, Interaction of cadmium, lead; Effect on growth, yield and content of $\mathrm{Cd}, \mathrm{Pb}$ in barley (Hordium vulgare). Indian $\mathrm{J}$ Environ Hlth 1986;28:235-243.

10. Yi TH Ching HK., Changes in protein and amino acid contents in two cultivars of rice seedlings with different apparent tolerance to cadmium. Plant Growth. Reg 2003;40:147-155.

11. Xu P, Zou J, Meng Q, Zou J, Jiang W, Liu D, Effects of Cd2+on seedling growth of garlic (Allium sativum L.) and selected physiological and biochemical characters. Bioresource Tech 2008;14:6372-6378.

12. Schutzendubel A, Schwanz P, Teichmann T, Gross K, Langenfeld-Heyser R, Godbold DL, Polle A, Cadmium induced changes in anti oxidative systems, hydrogen peroxide content and differentiation in Scots pine roots. Plant Physiol 2001;127:887-898.

13. Hagemeyer J, Breckle SW, Trace element stress in roots. In: Waisel Y, Eshel A, Kafkafi U, (eds.), Plant roots: the hidden half, 3rd edn. Dekker, New York, 2002. pp. 763-785.

14. Marcnano L, Carruyo I, Del Campo A, Monteil X, Effect of cadmium on the nucleoli of meristemetic cells of onion Allium cepa L.: An ultrastructural study. Environ Res 2002;88:30-35.

15. Costa G, Spitz E, Influence of cadmium on soluble carbohydrates, free amino acids, protein content in vitro cultured Lupinus albus. Plant Sci 1997;128:131140.

16. Costa G, Morel JL, Water relations, gas exchange and amino acid content in Cd-treated lettuce. Plant Physiol Biochem 1994;32:561-570.

17. Satyakala G, Studies on the effect of heavy metal pollution on Pistia stratiotes (water lettuce). Indian $\mathrm{J}$ Environ Health 1997;39:1-7.

18. Dinakar N, Nagajyothi PC, Suresh S, Udaykiran Y, Damodharan T, Phytotoxicity of cadmium on protein, proline and antioxidant enzyme activities in growing Arachis hypogaea L. seedlings. J Environ Sci 2008;20:199-206.

19. Dietz KJ, Baier M, Kramer U, Free radicals and reactive oxygen species as mediators of heavy metal toxicity in plants. In: Prasad MNV, Hagemeyer J, (eds), Heavy metal stress in plants: from molecules to ecosystems, Springer-Verlag, Berlin. 1999;pp.73-97.

20. Jana S, Effect and relative toxicity of heavy metals on Cuscuta reflexa. Water Air Soil pollut 1987;38:105109.

21. Manahan SE, Environmental chemistry. Lewis Publishers, Boston. 1990.

22. Mishra S, Agrawal SB, Interactive effects between supplemental UV-B radiation and heavy metals on growth and biochemical characteristics of Spinacia oleracea L. Braz. J Plant Physiol 2006;18:1-8.

23. Sun $Y$, Zhou Q, Diao C, Effects of cadmium and arsenic on growth and metal accumulation of $\mathrm{Cd}-$ hyperaccumulator Solanum nigrum L. Bioresource Technology 2008;99:1103-1110.

24. Hasan SA, Hayat S, Ali B, Ahmad A, 28Homobrassinolide protects chickpea (Cicer arietinum) from cadmium toxicity by stimulating antioxidants. Environ Pollut 2008;151:60-66.

25. Schat H, Sharma SS, Vooijs R, Heavy metal induced accumulation of free proline in a metal tolerant and non-tolerant ecotype of Silene vulgaris. Physiol Plant 1997;101:477-482.

26. Poschenrieder C, Barcelo J, Water relations in heavy metal stressed plants. In: M. N. V Prasad (Eds.), Heavy metal stress in plants. Narosa Publishing House, New Delhi, 2004;pp: 249-270.

27. Sakihama Y, Yamasaki H. Lipid peroxidation induces by phenolics in conjunction with aluminium ions. Biol Plantarum 2002;45:249-254.

28. Michalak A, Phenolic compounds and their antioxidant activity in plants growing under heavy metal stress. Polish J Environ Stud 2006;15: 523-530.

29. Sakihama Y, Cohen MF, Grace S, Hideo C, Yamasaki $\mathrm{H}$, Plant phenolic antioxidant and prooxidant activities: phenolics-induced oxidative damage mediated by metals in plants. Toxicology 2002;17:6780 . 